\title{
Surveying Healthcare Facilities for Tourists in India
}

\author{
Rajat Shandilya, Bhagyesh Acharya, Mayank, Monika Garg, Shobha Tyagi
}

Abstract: India is quickly becoming one of the most popular tourist destinations in the world. The rise of India as a tourist destination can be attributed to a number of factors. The growth of medical tourism in India is one of the reasons examined in this paper. Healthcare tourism is when people from all over the world fly to another country to receive medical, dental, and surgical treatment when exploring, vacationing, and completely immersing themselves in the attractions of the countries they are visiting. In the medical tourism industry, India is one of the most popular destinations. Medical tourism is experiencing rapid growth in India. Medical tourists cross foreign boundaries in search of medical care. Medical tourism has developed to become a multibillion-dollar industry. It is important to remember that the primary goal of medical tourists is to provide high-quality medical care at an affordable cost. When compared to other developing countries in the world, India has emerged as the most sought-after destination for medical tourists due to the availability of world-class doctors at affordable prices. In addition, India has a wide range of tourist destinations. It has tremendous potential for creating jobs and earning large sums of foreign currency. The paper ends with policy recommendations for advancing the rapidly growing medical tourism industry.

Keywords: Healthcare, Tourism, GDP.

\section{INTRODUCTION}

$\mathrm{H}_{\mathrm{s}}$ ospitals and the tourism sector work together to provide health care. Healthcare tourism is characterised as the provision of cost-effective private medical care in collaboration with the tourism industry for patients who need surgical or other types of specialised treatment. This process is aided by both the private sector and the tourism industry, both of which are active in medical care. Medical tourism is a rising industry, with several countries vying for a piece of the global medical tourism pie. Medical tourism was not well-known around the world just a few years ago, and it was difficult to imagine these two services coming together.

Manuscript received on 21 October 2021 | Revised Manuscript received on 04 November 2021 | Manuscript Accepted on 15 November 2021 | Manuscript published on 30 November 2021. * Correspondence Author

Rajat Shandilya*, Department of Computer Science and Engineering, Manav Rachna International Institute of Research and Studies, Faridabad (Haryana), India. E-mail. rajat.shandilya98@gmail.com

Bhagyesh Acharya, Department of Computer Science and Engineering, Manav Rachna International Institute of Research and Studies, Faridabad (Haryana), India. E-mail. bhagyesh.mukul@gmail.com

Mayank, Department of Computer Science and Engineering, Manav Rachna International Institute of Research and Studies, Faridabad (Haryana), India. E-mail. mayankgoel046@gmail.com

Monika Garg, Department of Computer Science and Engineering, Manav Rachna International Institute of Research and Studies, Faridabad (Haryana), India. E-mail. monikagarg.fet@mriu.edu.in

Shobha Tyagi, Department of Computer Science and Engineering, Manav Rachna International Institute of Research and Studies, Faridabad (Haryana), India. E-mail. shobhatyagi.fet@mriu.edu.in

(C) The Authors. Published by Lattice Science Publication (LSP). This is an open access article under the CC-BY-NC-ND license (http://creativecommons.org/licenses/by-nc-nd/4.0/)
Tourism and travel were once synonymous with unrestricted and unobligated leisure activities. Orthodox medical treatments such as Yunani, Ayurveda, homoeopathy, and naturopathy have been practised in India since ancient times. Travelers have come to India in the past to learn about these ancient traditions. Some states have now specialised in offering specific medical services. Ayurvedic treatments are available in Kerala and Karnataka, yogic practises and meditation are available in Uttarakhand, cardiac care, orthopaedic care, and other allopathic treatments are available in Delhi, and eye care is available in Chennai. Some of India's best tourist destinations are found in Karnataka, Kerala, and Uttarakhand. According to recent reports, the majority of customers who are usually urbanised are undergoing several types of surgeries like replacement of their knees, hips and dental surgeries that are performed by the expert and renowned doctors. Patients are given five star facilities in state-of-the-art hospitals and hence they are ready to pay high price for the treatments. People from even developed countries like the United States and Europe are flocking to India for medical care, and this is increasing rapidly as it allows them to save money on their medical bills. Besides the high costs, treatments including surgeries can take a long time, several months or years, that encourages customers to travel to developing countries like India for their serious health issues. Since many Medi-claim companies do not insure procedures like Cosmetic surgeries, many wealthy people in developing countries choose to go overseas for care. In the coming years, it will be interesting to see if health insurance providers promote medical tourism as just a potential costcutting strategy measure. In most emerging countries, hospitals enjoy cost management while adding flavour to health care facilities and promoting attractive packages to the consumers that include all of the facilities, ranging from medical treatment to voyage and generosity services to local tours, all in one deal. Medical tourism is highly trending because it offers both medical care and holiday, therefore the gap between hospitals and hospitality companies is narrowing.

\section{LITERATURE SURVEY}

According to recent reports, the healthcare sector faces the similar hurdles and growth as the Software and Pharma industries, which have shown in previous years. As per the reports, the exchange of nearly \$ 4 trillion and \$ 750 million shared by developing and developed countries, the health care industry is potentially emerging as one of the largest service sectors in developing countries.

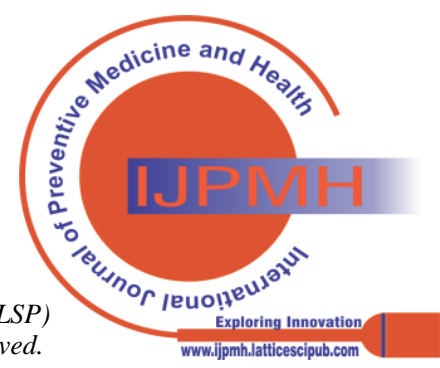




\section{Surveying Healthcare Facilities for Tourists in India}

According to the research, the global healthcare industry is growing to the tune of about $\$ 3$ trillion as a result of the amenities and facilities it offers, as well as the brand equity of Indian healthcare specialised all over the world. Medical knowledge is superior to that of other countries around the world. India is the best country on the planet, and the work performed by Indian doctors is recognised worldwide. The strong reputation of Indian health centres, which are recognised worldwide, is the key reason for India's emergence as a significant destination for healthcare. There are approximately 35,000 specialist doctors of Indian descent in the United States alone. International visitors admire Indian nurses for their nurturing demeanour, which they compare to motherly care. Since Indian health care industry is constantly upgrading its expertise, ability, and familiarity with the advanced technologies in the field, Indian health care business has begun to emerge as a favourite destination for undergoing medical treatment for foreign tourists.

And making its image more human in terms of eminence and cost Yoga has been practised for more than 5,000 years. Many students of foreign origin from medical and healthcare field flock to India to learn the concepts of Yoga and other types of remedial techniques like Naturopathy and Ayurveda. When Buddhism arrived in India 2,500 years ago, it quickly established itself as the epicentre of Eastern artistic expression. In comparison to Western allopathic medicine, that is also more popular and reputable all over the world, India is now one of the most well-known and safest destinations for international patients due to its natural and ayurvedic medical practitioners.

\section{HISTORY OF HEALTHCARE TOURISM}

Healthcare tourism is not a brand-new phenomenon. It dates back thousands of years, when Greek pilgrims from all over the Mediterranean flocked to Epidauria to worship the healing god Asklepios. Spa towns and sanitariums can be thought of as an early example of medical tourism. For example, in Patients visited spas in the eighteenth century in England because they were places of supposedly healthgiving mineral waters, treating diseases such as liver disorders, skin problems, and so on. People have travelled to neighbouring countries to boost their health since the 19th century, when there were no limits on travel in Europe. In the twentieth century, however, health tourism has grown to a much larger scale, with Thailand, India, Argentina, Cuba, China, and other countries being the most prominent health-care destinations.

Medical tourism has a long tradition in many countries around the world. Health tourists used to come from all over the world to enhance their health in ancient times. The explanation synonym for medical travel is substantially different from the preceding and can best be defined as travel by the middle class from developing countries to a foreign country in order to escape long lines of waiting. For this reason, international travellers flock to the well-known destination to reduce treatment delays, obtain inexpensive, high-quality medical care, or simply have elective surgery combined with sight-seeing and other local tourism opportunities (Gray and Poland). Ayurveda, yoga, Unani, Allopathy, Naturopathy, Meditation, and other medical treatments are common in India. The medical tourists came from rich countries like the United States, Canada, the United Kingdom, Singapore, Malaysia, Jordan, Saudi Arabia, and parts of South America. Now India is the most preferred choice among the medical care seekers, the industry has been growing tremendously in other parts of the world.

\section{WHY INDIA: REASONS FOR GROWTH OF MEDICAL TOURISM IN INDIA}

India has a more than 5000-year-old civilization and is noted for its cultural and religious diversity, as well as various geographical landmarks. Popular arts and crafts add to the charm of the area in order to draw visitors. In India, visitors are considered as gods, and the same is true for tourists. Ayurveda, Siddha, Unani, Naturopathy, and Yoga are examples of indigenous or conventional health care practises in India. Patients come from all over the world to visit. The main drivers that inspire a patient to travel to India for medical treatment, from the perspective of the customer, i.e. the medical tourist, are:

- Treatment is delivered at a low rate that is equivalent to every other destination in developing countries.

- Major tourist destinations such as Goa, Agra, Jaipur, Kerala, and others are available. This provides a further opportunity for medical tourists.

- Favorable exchange rates of developed countries in comparison to India. This makes the travelling and lodging cheap for people from these countries.

- Possibility of on line diagnosis especially for post care and future consultations.

- India provides state-of- art facilities because of the specialized doctors, nurses and paramedical staffs.

- Strong Pharma Sector and gaining worldwide recognition.

- $\quad$ Large pool of doctors (Over 650,000).

- Yoga \& Ayurveda as alternative treatments.

- Nurses \& paramedics - Highly skilled experts with good communication skills.

- Flight connectivity is good.

- Availability of hospitals with International accreditations.

Some important reasons which are cited for the growth of medical tourism in India are:

- Communication- India is a country where Patients are communicated with by healthcare practitioners and physicians in English and other languages. Despite the fact that India has a diverse language landscape, English is widely spoken. Many of the hospitals have outstanding English-speaking staff and provide simple communication facilities. The hospital industry has also made translation arrangements in order to improve contact.

- Cost factors - The low cost of care is one of the reasons for the rise of medical tourism. In comparison, the cost of care for various surgeries is less than 20\% of the cost of services in Western countries. For example, the United States, Canada, China, Tunisia, South Africa, Kazakhstan, and other countries charge a high price for various surgeries.

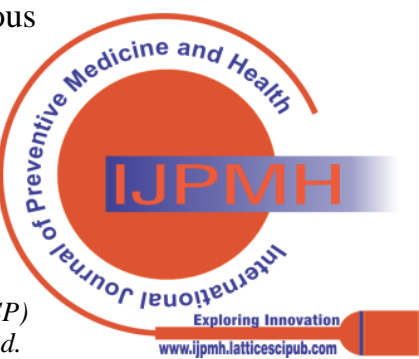


- Growth - India is experiencing rapid growth in medical tourism. Because of the positive support of the Indian state and government. Medical services are also being boosted by the government and the Aadhar corporate sector. The Indian government is working to build a strong infrastructure in the region. As a result, enormous development has occurred in order to draw medical tourists. The Indian government has made various facilities available to healthcare travellers.

\section{OBJECTIVES}

This section lists the objectives of this study:

- To study the drivers and mechanism of medical and healthcare tourism.

- To investigate the main drivers and challenges of Indian tourism for healthcare.

- To investigate the current state of the medical tourism industry in India.

- To analyse monthly data and state-by-state data, the prospective and developmental areas of the medical tourism industry in India can be determined.

\section{THE MECHANISM OF MEDICAL TOURISM INDUSTRY}

The trends of medical tourism have been observed in recent decades, which indicate ambiguity and unidirectional nature. Similar to normal tourism, tourists consider their preferences such as the type of vacation, the amount of time they want to spend on vacation, the amenities, infrastructure, and the amount of money they want to spend on vacation, and then they consider the area in which they want to stay and choose the best hotel.

However, the proper mechanism of healthcare tourism can be stated as follows: Initially the patient determines their own needs and desires in relation to their medical condition. Then they proceed to the next step, which is to choose a country with the best medical facilities in accordance with their affordability.

This is the final step in the medical tourism process. As a result, it can be inferred that cost is not the most important consideration when selecting medical tourism services.

\section{SITUATION OF HEALTHCARE TOURISM INDUSTRY}

According to the CII (Confederation of Indian Industries), India's medical facilities are one-of-a-kind. In comparison to other countries in the world, India offers Yoga in addition to Allopathy, along with observation, Ayurveda, Homoeopathy, and other structures of medicine, making it a unique hub of medical services.

Many foreign patients are drawn to Ayurvedic care because of the natural and inherent cultural dimension. Kerala has been a popular destination for this treatment for many years, and visitors from Britain, America, Germany, Spain, France, and Sri Lanka. Healthcare tourism is a rapidly expanding industry in India.

The current size of the Indian medical tourism industry is projected to be just over $\$ 3$ billion, with predictions that the industry will grow to $\$ 6$ billion by 2018. Along with biotechnology, this is one of the main drivers of the Indian economy also along with software technology. There are several private and public hospitals that offer medical care to patients of all ethnic backgrounds.

VIII. OPPORTUNITIES OF HEALTHCARE
TOURISM IN INDIA

- INSTANT TREATMENT IN DEVELOPING COUNTRIES: Long hospital wait times in developed countries are one of the key motivators for foreign patients to seek treatment in other countries. In countries such as the United Kingdom, patients must wait 10 to 12 months for surgery. However, in developing countries such as India, Thailand, and others, there is no such thing as a waiting period. The patient is free to be treated anytime he wants.

- INCREASING PRIVATIZATION

AND

INVESTMENT OPPORTUNITIES IN

- TOURISM AND HEALTHCARE SECTOR IN INDIAN ECONOMY: Increased private sector participation in recent years has resulted in Indian hospitals investing heavily in infrastructure and equipment to make them internationally competitive, with a focus on the Indian elite class and international patients.

- FLUENT ENGLISH SPEAKING HOSPITAL STAFF: One of the key advantages is that English is commonly spoken and understood in India, which attracts many English-speaking patients from various countries. Countries such as Thailand, China, and others, on the other hand, lack this consistency.

- DESTINATION WITH INCREDIBLE ATTRACTION:India is the most popular and exciting tourist destination on the planet. The country is known for its diverse culture, history, heritage, people and lifestyles, fairs and festivals, wine, wildlife, deserts, beaches, and snow-capped Himalayan peaks.

- AFFORDABLE COST OF MEDICAL TREATMENT: In developing countries, the cost of medical services is $60-80 \%$ higher. In terms of personnel, facilities, and healthcare procedures, India is the cheapest of any of the world's healthcare tourism destinations, while still being equivalent to or better than other major destinations. Foreigners are rapidly flocking to India because it provides high-quality treatment at a fraction of the cost in other countries. Complicated surgical procedures in India are performed at a fraction of the cost of procedures in developed countries.

- REDUCED COST OF INTERNATIONAL TRAVEL AND TOURISM: India has all of the amenities that visitors need in large quantities. A increasing number of easy, low-cost non-stop or one-stop flights to India are available. As a result of all of this, tour packages to India are inexpensive, attracting visitors from all over the world.

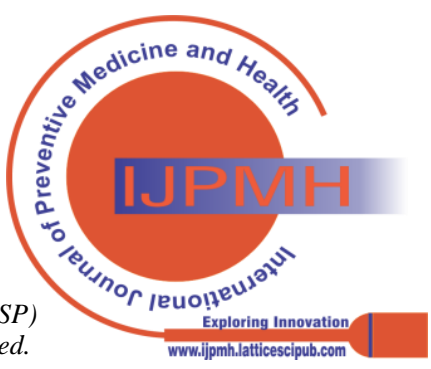




\section{Surveying Healthcare Facilities for Tourists in India}

- FOREIGN PATIENTS CAN GET PACKAGE DEALS INCLUDING FLIGHTS,

- TRANSFERS, HOTELS, TREATMENT \& POST OPERATIVE VACATION FOR THEIR VISITS: With the participation of the private sector and the tourism industry, it is now easier for patients to travel to foreign countries for care, as they can now obtain treatment package packages that include tickets, transfers, accommodation, treatments, and leisure activities.

- INCREASING DEMAND FOR WELLNESS TOURISM AND ALTERNATIVE CURES: Alternative healthcare approaches are becoming more common in developing countries as a result of the fastpaced lifestyle. India is home to some of the world's most interesting alternative healthcare practises, such as yoga, Ayurveda, homoeopathy, and naturopathy, which inspire international visitors to come to India.

- AVAILABILITY OF ALTERNATIVES HEALTHCARE PRACTICES: the existence of alternative treatment techniques like Yoga, Naturopathy, Ayurveda, and other systems of medicine are becoming increasingly common among international patients as non-surgical treatments for a variety of ailments. Ayurveda and Kairali Massage are common in Kerala. Some of the world-famous places in India for alternative medicine include Uttarakhand for yoga and meditation, Goa for holistic living, and Rajasthan for spas and heritage living. These activities are the primary ancestral assets that offer India a significant opportunity to grow healthcare tourism and gain significant foreign exchange from developed countries.

\section{IX.CHALLENGES TO HEALTHCARE TOURISM IN INDIA}

- LACK OF INSTITUTIONAL TIE-UPS BETWEEN DIFFERENT PLAYERS OF

- INDUSTRY : One of the major problems for the Indian healthcare tourism industry is a lack of cooperation and tie-ups between various industry players (hospitals, insurance firms, and travel companies). This coordination is essential for India's development of this industry.

- LACK OF INTERNATIONAL ACCREDITATION : One of the most significant challenges facing the Indian healthcare industry is that the majority of Indian hospitals are not accredited by any foreign accreditation agency such as JCI, ISO, NABH, or others. Either these hospitals do not meet the agency's requirements, or they are not serious about obtaining accreditation from an international organisation.

- OUTDATED INFRASTRUCTURE AND COMMUNICATION FACILITIES: Since India is a developing nation, its infrastructure and communication system are still in their infancy. It is in no way comparable to developed countries.

- RISK OF INFECTION FROM FOREIGN PATIENTS: One of the major disadvantages of developing healthcare tourism is the possibility of serious diseases being transmitted to locals by foreign tourists. The industry faces a significant challenge in reducing this risk.

- CUSTOMER PERCEPTION AS AN UNHYGIENIC COUNTRY: India is one of the world's fastest developing countries; it is improving in all areas, but sanitation remains a problem. In the eyes of the rest of the world, India is regarded as a filthy republic.

- NON-UNIFORMITY OF PRICING POLICIES IN HOSPITALS ACROSS INDIA: The Indian healthcare sector does not have adequate pricing strategies. There is a significant price gap between hospitals for the same care or service. For care, each hospital sets its own price. These disparities in pricing cause patients to be perplexed.

- LANGUAGE BARRIER FOR NON-ENGLISH SPEAKING CUSTOMERS: Without a doubt, English is commonly spoken and understood in India, which is one of the primary benefits since it attracts a large number of English-speaking patients from various countries. However, since there are many non-English speaking customers from various countries, language remains an obstacle. It's also difficult to offer decent care to them if you don't speak their language.

- INAPPROPRIATE ROADS, SEWERAGE \& SANITATION, PUBLIC UTILITIES ETC.: India is progressing in all fields, from agriculture to various industries, but it still lacks proper infrastructure, such as highways, sewage systems, and public utilities. These buildings are in terrible shape.

- IMPROPER WASTE MANAGEMENT SYSTEM : Waste from various industries or households causes a variety of issues, such as diseases and pollution. As a result, proper waste management from various industries is a prerequisite of this global period. However, India lacks a proper waste management scheme.

- UNAVAILABILITY OF PROPER INSURANCE POLICIES FOR THIS SECTOR: The healthcare tourism industry in India is also facing several challenges in terms of insurance and allied services.

- NO STRONG GOVERNMENT SUPPORT: The government has a critical role to play in improving the healthcare tourism market. However, the government has always regarded business as a stepchild, resulting in the following issues, which are caused by the government. There are six of them: (a) no rules, (b) tax irregularities, (c) bureaucratic roadblocks, (d) no land reforms, and (e) a lack of long-term investor-friendly policies.

\section{SWOT ANALYSIS OF MEDICAL TOURISM IN INDIA}

The current state of the Indian medical tourism industry's SWOT (Strengths, Weaknesses, Opportunities, and Threats) review is as follows:

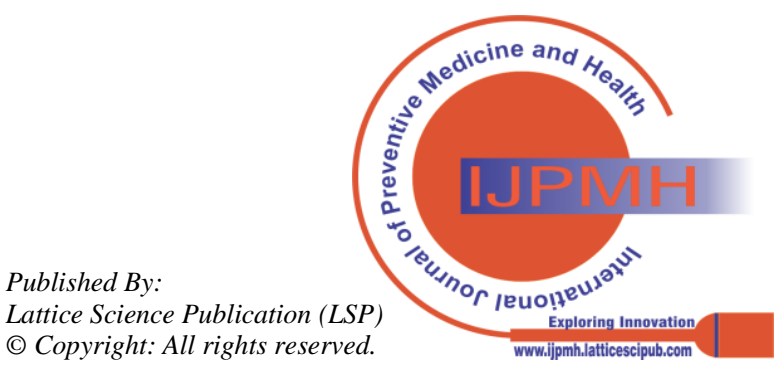




\section{STRENGTHS:}

- Huge supply of qualified doctors.

- World class reputation of hospitals and Doctors.

- Quality Service at Affordable Cost.

- Diversity of experiences and tourism destinations.

- Availability and success in advanced healthcare like Cardiovascular, organ transplants - high success rate in operations.

\section{OPPORTUNITIES:}

- Increase in the demand for healthcare services from countries with aging population (U.S, U.K)

- Fast-paced lifestyle increases demand for alternative cures and wellness tourism.

- Short supply in National Health Systems in countries like U.K, Canada.

- Demand for retirement homes for elderly people specially in Japan.

- Demand from countries with underdeveloped healthcare facilities.

\section{WEAKNESSES:}

- Strong competition from countries like Singapore, Thailand, Malaysia.

- Overseas medical care not covered by insurance providers.

- No big government support/ initiative to promote medical tourism.

- Very less Coordination between the various players in the industry- airline operators, hotels and hospitals.

- Improper accreditation and regulation system for hospitals.

- Lack of uniform pricing policies across all hospitals.

\section{SUGGESTIONS}

The following recommendations chart a course for India's future development as a unique destination for healthcare tourism.

- PUBLICITY OF THE HEALTHCARE PRODUCT: Requirement of Publicity materials, such as blogs, mainstream magazines, guide books for tourists, business magazines, and tourism journals, to be distributed to target markets.

- PROMOTE THE PUBLIC-PRIVATE PARTNERSHIP: To promote the growth of healthcare tourism in India, public-private partnerships must be encouraged so that various financial and policy challenges can be addressed quickly.

- PROMOTING INTER-SECTORAL COORDINATION: Government bodies, such as the National Association of Health Tourism (NAHT), should be in charge of organising the activities of various players, such as hospitals, tourism departments, transportation operators, hotel associations, and escorts.

SETTING UP NATIONAL LEVEL BODIES: Leading private hospitals across the country should prepare to establish a national-level body with the aim of promoting India as a hot healthcare tourism destination in order to market India's specialised healthcare products in the world and to resolve the numerous issues confronting the corporate healthcare sector.
- ROLE OF GOVERNMENT: The role of The performance of the Indian government in healthcare tourism is based on two factors:

a) To create customer trust, acting as a regulator to establish a standard grading and accreditation framework for hospitals.

b) Assisting in the facilitation of private investment in healthcare facilities and policy development in order to improve healthcare tourism.

\section{CONCLUSION}

India is in a good position to take advantage of global medical tourism opportunities. The government's position in the growth of medical tourism is critical. The government should take measures to act as both a regulator and a facilitator of private healthcare investment. Patients should be able to contact the Immigration Department at any point of entry for swift clearance, allowing for faster visa grants to international visitors for medical reasons. Some of the policies that can be implemented include tax benefits for service providers, reduced import duties on medical supplies, and committees to encourage and foster medical tourism. To promote tourism in India, it is also essential to build supporting infrastructure such as transportation services. For effective patient care, the tourism, wellness, information, and communication departments must collaborate. Some medical tourism strategies have been suggested in this paper for further promoting medical tourism in India. These include enhancing India's reputation as a high-quality medical tourism destination, developing and promoting new medical tourism product combinations, maintaining a high standard of quality treatments at a fair cost, and making comprehensive online and offline materials accessible to potential customers. Accreditation/standards must also be obtained to ensure the consistency of treatments, as well as a focus on the needs and demands of the current target markets.

\section{REFERENCES}

1. Begum,S. (2013):, "Medical and Wellness Tourism: Opportunities and Challenges Marketing „Brand India ${ }^{e e,, ~ R e s e a r c h ~ J o u r n a l ~ o f ~}$ Management Sciences Vol. 2(1)

2. DAWN, S.K. \& PAL, S. (2011), "Medical Tourism in India: Issues, Opportunities and Designing Strategies for Growth and Development", International Journal of Multidisciplinary Research Vol.1 Issue 3.

3. Priyambada, P., Choudhary, M. \& Singh,R.K (2014), "An overview on opportunity of Medical Tourism in India", Tropical Journal of Pharmaceutical and Life Sciences, Vol.1, No.1, 26-33.

4. Kalyan Chakravarthy K., Kumar, C H. Ravi and Deepthi(2008), "Swot Analysis On: Medical Tourism", Conference on Tourism in India - Challenges Ahead, IIMK

5. Bhadu,S.S (2011), "Opportunities \& Challenges of Medical and Health Tourism- Creating A Brand of alternative Tourism in India", IJMT, Volume 19, Number 2.

6. Singh, L. (2014), "An evaluation of medical tourism in India", African Journal of Hospitality, Tourism and Leisure Vol. 3 (1).

7. Kaur, J., Sundar, H., Vaidya, D \& Bhargava,S.(2007), "Health Tourism in India Growth and Opportunities", International Marketing Conference on Marketing \& Society, IIMK

8. Abhyankar, A. 2013. Growth potential of the domestic and international tourism in India. Review of Integrative Business \& Economics Research, 2(1):566576. 


\section{Surveying Healthcare Facilities for Tourists in India}

9. Awadzi, W and D. Panda. 2007. Medical tourism: globalization and the marketing of medical services. The Consortium Journal, 11:7581.

10. BBC. 2005b. India plans for medical visas . July 8. [http://news.bbc.co.uk/2/hi/south_asia/4665961.stm] Accessed 10/14/2005.

11. Bookman, M. Z., and K. R. Bookman. 2007. Medical tourism in developing countries. Palgrave MacMillan: New York. [CrossRef]

12. Carrera P. and J. Bridges. 2006. Globalization and healthcare: Understanding health and medical tourism. Review of Pharmacoeconomics and Outcomes Research, 6(4) 447-454. [CrossRef]

13. Chanda, R. 2013. Medical value travel in India: Prospects and challenges. In Travelling well: Essays in medical tourism. Labonté, R., Runnels, V.,Packer, C. and Deonandan, R. (eds.) Transdisciplinary studies in population health series, 4(1) Ottawa: Institute of Population Health, University of Ottawa.

14. Ehrbeck, T., C. Guevara, and P. Mango. 2008. Mapping the market for medical travel. The McKinsey Quarterly, May.

15. Consumerism Commentary. 2009. Medical tourism sample surgery cost chart. Adapted from the medical tourism association. July. [http://www.consumerismcommentary.com/popularity-of-medicaltourism- increasing/] Accessed 2/19/2010

16. Fortis. 2013. Fortis Healthcare. Information on Fortis Hospitals. [http://www.fortishealthcare.com/] Accessed 7/12/13

17. Garcia-Altes, A. 2004. The development of health tourism services. Annals of Tourism Research, 32(1):262-266. [CrossRef]

18. Gill, H. and N. Singh. 2011. Exploring the factors that affect the choice of destination for medical tourism. Journal of Service Science and Management, 4:315- 324. [CrossRef]

19. Goodrich, J. N. and G.E. Goodrich. 1987. Health-Care tourism An exploratory study. [CrossRef]

20. Tourism Management, 8(3):217-222. September.

21. Gupta, S. 2004. Medical tourism and public health. People $\square$ s Democracy. 28:19, May.

22. Hazarika, I. 2010. Medical tourism: its potential impact on the health workforce and health systems in India. Health Policy and Planning, 25:248-251. [CrossRef]

23. Lal, N. 2010. India s medical tourism industry. The Asia sentinel. June 2. [http://yaleglobal.yale.edu/content/indias-medical-tourismindustry] Accessed 2/22/12.

24. Laws, E. 1996. Health tourism: A business opportunity approach. In Health and the International Tourist. S. Clift and S.J. Page (Eds.). London: Routledge. pp. 199-214.

25. NaRanong, A. and V. NaRanong. 2011. The effects of medical tourism: Thailand s experience. Bulletin of the World Health Organization, 89:336- 344 [CrossRef]

26. Patients Beyond Borders. 2011. Medical tourism statistics and facts. [http://www.patientsbeyondborders.com/medical-tourism-statisticsfacts] Accessed 2/10/12.

27. Satish, G. 2005. Medical tourism likely to become India s next big success story. Garamchai. $\quad$ October 8. [http://www.garamchai.com/MedicalTourismArticle1.htm] Accessed 1/13/2006.

28. Schult, J. 2006. Beauty from afar: A medical tourist s guide to affordable and quality cosmetic care outside the U.S. Harry N. Abrams, Inc: New York.

\section{AUTHOR'S PROFILES}

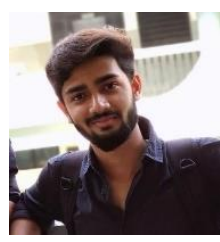

Rajat Shandilya is a Computer Science graduate from Manav Rachna International Institute of Research and Studies. He along with his team mates came up with a solution to a problem which could help a large number of people traveling to India for medical treatment.

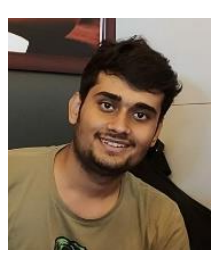

Bhagyesh Acharya is a graduate in Cyber Security and Forensics from Manav Rachna International Institute of Research and Studies. He along with his team mates wrote this research paper to attract foreigner tourists to India for medical treatment.

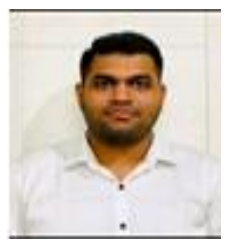

Mayank is a graduate in Cyber Security and Forensics from Manav Rachna International Institute of Research and Studies. Currently he is pursuing PGDM from New Delhi Institute of Management.

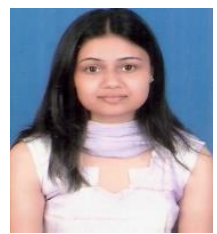

Monika Garg Specializes in the field of Data Mining and Machine Learning. Working as an Assistant Professor in the department of Computer Science and Engineering, Manav Rachna International Institute of Research and Studies. She has several research articles published in renowned journals and indexed in reputed databases- SCIE and Scopus.

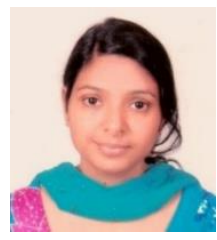

Shobha Tyagi is working as an Assistant Professor in the department of Computer Science and Engineering, Manav Rachna International Institute of Research and Studies. Her research areas are Open source software, Image Processing and Blockchain Technology. 